(C) М.А. Андрюнина

\title{
ПОГРЕБАЛЬНАЯ И ПОМИНАЛЬНАЯ ОБРЯДНОСТЬ ПРУЖАНЩИНЫ ПО МАТЕРИАЛАМ ПОЛЕВОЙ ЭКСПЕДИЦИИ 2019 г. В ПРУЖАНСКИЙ РАЙОН БРЕСТСКОЙ ОБЛАСТИ БЕЛОРУССИИ*
}

\begin{abstract}
В статье представлены полевые материаль автора, описывающие цчикл похоронно-поминальной обрядности населения западного Полесья (Пружанский район Брестской области). Собранные в результате недавней этнолингвистической экспедиции данные подтверждают высокую степень сохранности архаических мотивов и традиций в Пружанском районе. В то же время они позволяют отметить распространение здесь ряда инноваџий (напр., появление новой для этого региона весенней поминальной дать “Радуница"), очертить механизмы изменения и дезинтеграчии культуры, часто происходящих в связи с вмешательством иеркви, запретившей ряд традиционных погребальных и поминальных практик. Со слов респондентов были записаны редкие сюжеты (например, о душах животных, о способах «отмолить» самоубийиу пр.), а также приводятся примеры из других сфер традиционной духовной культуры, например, демонологии (поверья о ведьмах, русалках и нечистых покойниках), окказиональные обряды (вызывание дождя), терминология, касающцаяся лунного времени, народного календаря и пр. Обнаружены возможные параллели с другими диалектными регионами славянского мира (напр. связь “русалки” и росы с плодородием житного поля в Полесье и Болгарии).
\end{abstract}

Ключевые слова: Полесье, полевые материаль, похороны, поминки, традиционная культура.

В июне 2019 года состоялась международная этнолингвистическая экспедиция в западное Полесье, организованная Центром исследования белорусской культуры, языка и литературы НАН Беларуси, некоторые результаты которой предлагаются вниманию читателей в данной статье (первая их часть, посвященная свадебной и родинной обрядности, была опубликована в № 42019 г). Важность исследований

Андрюнина Мария Александровна - к. филол. н., научный сотрудник Института этнологии и антропологии РАН (Москва, Ленинский пр., 32А). Эл. почта: mary-andr@mail.ru. Andrunina, Maria A. - Institute of Ethnology and Anthropology, RAS (Moscow, Leninsky Pr., 32A). E-mail: mary-andr@mail.ru

* Публикуется в соответствии с планом научно-исследовательских работ Института этнологии и антропологии РАН

${ }^{1}$ Автор выражает благодарность Н.П. Антропову, принявшему на себя труд по сверке и редактуре всех приведенных в статье диалектных текстов; а также другим сотрудникам Центра Е.М. Боганевой, Т.В. Володиной и работникам домов культуры Пружанского р-на. 
Полесского региона для славистики и диалектологии, компаративных, кросс-культурных и межрелигиозных штудий, равно как и для реконструкции древнейших состояний и развития языка и традиционной культуры трудно переоценить. Помимо пограничного положения Полесья на стыке территорий расселения трех восточнославянских народов и одного западнославянского (украинцы, белорусы, русские, поляки), этот регион был признан одним из старозаселенных мест, преемственность археологических древностей и групп населения которого фиксируется с эпохи неолита (Кухаренко 1965, Кухаренко 1968). Это проявляется в не раз подтверждавшейся, в том числе и в результате нынешней экспедиции, удивительной сохранности огромного массива сюжетов и фрагментов традиционной народной культуры, которые лишь разрозненно существуют в ряде других территорий со славянским населением. Давно выявлены широкие и архаические связи Полесья с рядом славянских диалектных континуумов - не только с соседними украинским и белорусским, но и с псковской, новгородской, олонецко-архангельской, черниговско-брянской, карпатской, мазовецкой, и далее с южно- и западнославянскими диалектными зонами (см.: Толстой 1968, Мартынаў 1971).

В нашей экспедиции материал собирался ее участниками как по индивидуальным программам, посвященным погребальной и поминальной обрядности, народной Библии и народной медицине, так и по программам Полесского этнолингвистического атласа (полной и сокращенной). Последние использовались по причине их удобства не только для последующего картографирования данных, но и для комплексного обследования традиционной духовной культуры, наблюдения за ее сохранностью и изменениями, включающими размывание и инновации. Приведенные в статье диалектные тексты (с переводом на русский язык) представляют собой образец живой речи жителей исследованных нами сел, приводимый в орфографии, принятой для Полесского архива Института славяноведения РАН (Полесский архив), которая была опробована при публикации полесского материала в ряде авторитетных научных изданий (см. напр.: Толстая 2005, Винорадова, Левкиевская 2010).

\section{Погребальная обрядность}

\section{Приметы смерти}

1. [Какие приметы предвещают смерть?] Да прымет, канечно, многа. Гаварыли, што дом деревянный и трашчыт проста дом, ну ета ўжэ гаварыли, што к пакойнику. [Где именно трещит?] Йесьли трэск идзе па хацэ так, без прачыны, ета к пакойнику [РЕИ] (Ровбицк).

2. Ну, напрымер, мой брат памьёр, жыў ў Маскоўской обласци, кукушка прыляцела мне на дэрэво коваць, паковала и ўляцэла. Я думаю: што можэ быць?
1. Смерть предвещает много примет. Говорили, что необъяснимый треск в деревянном доме - к покойнику. Если беспричинный треск идет по дому, это к покойнику [РЕИ] (Ровбицк).

2. Ну, например, когда умер мой брат, а он жил в Московской области, мне на дерево прилетела кукушка, куковала и улетела. Я думаю: «Что может быть?» И 
И ў дэкабрэ гэта случылася. А перад мужыком [перед смертью мужа] прылятала на тую сторону, на грушу села, тожэ куковала. И ана куковала самаю ранняй вясной, и 13 июня он памьёр. Эта кукушка прэдсказывае. Йесьли кукушка прыляцела пад двор, гэта ужэ не на дабро, гэто ужэ знаеш, што што-та [плохое] будзе [СЕВ] (Клепачи).

3. [К чему снится конь?] Сматря який: белый конь - к пакойнику, красный, гавараць, к пажару [ПЕА] (Клепачи).

\section{Агония}

1. [Расскажите про агонию. Чем ее обегчали?] Сканаў. Кана́е. Брали сьвечку, грамничныя сьвечки ${ }^{1}$, ну, брали сьвечку, запаливали. И за́рэ у меня муж памёр, я рабила. Парахрысциш яго йетай сьвечкай, абвядуць тры раза, абвяла вакруг яго и дала яму ў руки падзяржаць, каб гарэла. Чужым так рабила, а сваему мужу расцяралася... [РНП] (Юндилы).

2. Маци памирала, сьвечку зажыгали любую, лишь бы сьвечка была [CEВ] (Клепачи).

3. Мая баба казала, што чалавек перад сьмерцю должэн памучыцца. Наабарот, шчытали, што йесьли раптово умёр, зарэ радуюцца: «Ой, упал, умьёр». А баба мая кали казала: «Трэба, коб пакойник паляжаў хоць нядзелю чи дзьве перад сьмерцью, памучыўса за сваи грэхи, за ўсё, коб трэба». А як раптовно умрэ, гэто ўсё, с грэхами пашоў на тот сьвет. [Нужно ли было при этом близким соблюдать тишину?] Да, да, як умираець, нельзя шумець, перэбьешь сьмерць, казали, перэбьеш. Не трогайце, умиpae, перэбьеш, нельзя, патому што як

1 Свечи, освященные в церкви в праздник Громницы (Сретение, 2/15 февраля). в декабре это случилось. А перед смертью мужа прилетела на другую сторону, села на груше и куковала. Она куковала самой ранней весной и 13 июня он умер. Это кукушка предсказывает. Если кукушка прилетела на подворье, это не к добру, это уже знаешь, что случится чтото плохое [CEВ] (Клепачи).

3. Белый конь снится к покойнику, красный, говорят, к пожару [ПЕА] (Клепачи).

1. Агонию облегчали громничной свечой, ее зажигали. И я так делала, когда умирал мой муж. Перекрестишь его этой свечкой, обведут вокруг него этой свечой три раза, обвела три раза и дают умирающему ее в руках подержать, чтобы она горела. Чужим людям я так делала, а когда мой муж умирал, растерялась...[РНП] (Юндилы).

2. Когда мать умирала, зажигали любую свечку, лишь бы свечка была [CEВ] (Клепачи).

3. Моя бабушка говорила, что человек перед смертью должен помучиться. Наоборот, считали, что если человек внезапно умер, вот сейчас радуются: «Ой, упал, умер». А бабушка моя раньше говорила: «Нужно, чтобы покойник полежал хоть неделю или две перед смертью, помучился за свои грехи, за все, что нужно». А если внезапно умер, это все, с грехами пошел на тот свет. Когда человек умирает, нельзя шуметь, иначе, говорили, перебьешь ему смерть. Не трогайте умирающего, перебьешь ему смерть, нельзя, потому что если перебьешь, то он будет еще долго мучиться. Даже говорили: 
перэбьеш, то буде йешчэ... [долго мучиться]. Даже говорыли: «Ой, мучыцца, перэбили [смерть]». Пабачыла, што ўмирае, жонка падбегла, стала трясьци, плакаць, и зарэ ўжэ [он] от мучыца. [Как говорили про агонию?] «Душу Богу атдае». «Канае», есьли непрыязь; есьли нармальнае атнашение, такого слова не гаварыли. Это ужэ слишкам - канае [БВВ] (Оранчицы).

4. Мая мама як умирала, так начали крычаци, ей перабили [смерть], и ана цэлые сутки ляжала, ужэ без сазнания была, но ўсё раўно страдала. Казали, тады выганяли из хаты [всех], коб не крычали, патаму что далжна уйци, жыць ужэ не будэ, а будэ мучицца [ПЛВ] (Хорева).

5. [Кто мог тяжело умирать?] Гэто, гаварыли, что яны [колдуны] доўго ўмираюць, дажэ и паталок [снимают]. У нас там адни чараўники были, казали, што яны ўсё гэто варажыли; ну, гэто прастую малитву гаворыш, дзицям памагаеш, а як чаруеш, гэто ци што робиш, гэто грэшно; так [они] умираюць вельми цяжэло. Дажэ сьнимали паталок, на пол ложаць [умирающего], на зямлю [РНП] (Юндилы).

6. Тут вспомнила: напроциў дом такий стаял, там жыла бабушка, ана, гаварыли, што вельми многа ўсяго знае, ўсякие силы. Ана с кем-то там гаварыла [когда умирала], но ей ужэ многа лет нема, но я яе чуць-чуць помню, и вот ана як умирала, ана тры дня ляжала, не магла памерци: и не жыла, и не умирала, вот такее вот. То гаварыли, что дажэ пако́т [разбирали], до́ску паднимали, штоб дух нядобры вышэл. Яе не атпускало што-то с йетаго сьвету. Я слышала, што так гаварыли, што здирали пако́цину, штоб ана магла ўме́рци; и правда, ана тады ўме́рла. [Она должна была передать свои “умения”?] Ну, да, так га-
«Ой, он мучается, ему перебили смерть». Увидела жена, что муж умирает, подбежала, стала его трясти, плакать и он уже снова мучается. Про агонию говорили: «Отдает Богу душу». «Конает», говорили, если испытывали к этому человеку неприязнь, если относились нормально, такого слова не употребляли. Это уже слишком [БВВ] (Оранчицы).

4. Когда умирала моя мама, то начали кричать и перебили ей смерть, и она лежала еще целые сутки, была без сознания, но все равно страдала. Говорили, что нужно выгонять из дома всех, чтобы они не шумели, потому что умирающая должна уйти, она уже не будет жить, а только мучиться [ПЛВ] (Хорева).

5. Говорили, что долго умирают колдуны и им даже снимали потолочные доски. У нас там были одни колдуны, говорили, что они все это ворожили; когда читаешь обычную молитву (заговор - прим. соб.), помогаешь детям (лечишь - это нормально), а когда колдуешь или портишь, это грешно, поэтому колдуны умирают очень тяжело. Им даже вынимали доски из потолка, клали умирающих на землю, чтобы облегчить агонию [РНП] (Юндилы).

6. Тут вспомнила: напротив стоял дом, а в нем жила бабушка, говорили, что она очень много знает, что она колдует и у нее есть всякие силы. Когда она умирала, она с кем-то говорила, ее нет уже много лет, но я ее немного помню, и вот когда она умирала, то она лежала три дня и не могла умереть, и не жила, и не умирала, вот такое. Говорили, что ей даже разбирали потолок, поднимали доску, чтобы из нее вышел злой дух. Ее что-то не отпускало с этого свету. Я слышала, что так говорили, что выдирали потолочную доску, чтобы она могла умереть, и правда, она тогда сразу умерла. Говорят, что нужно кому-то передать эти свои таланты, иначе будешь 
воряць, што трэба каму-та перэдаць гэта свае таланты, иначэ можэт быць цяжко. Жэншчыне вынимали гэту пако́цину ў хацэ, ана не магла умэрци, трое сутак ляжала такая и гаварыла: «Сы́но, што дай мне руку, дай мне руку». А он не захацеў, ана так долга ўмирала, и ей выдзирали пако́цину гэту [РЕИ] (Ровбицк).

7. [Разбирали ли потолок, чтобы облегчить агонию ведьме?] Ну, так ведзьма какая умирала, разбирали. Есьли ведзьма, то разбирали, гэто точно. [Она должна передать?] Далжна абязацельно, тагда ана лягчэй умрёць. [Как это делалось?] Трэба быць адзин на адзин, коб никаго не было пастаронних, ана хочэ перэдаць, гэто было тайно... У нас тожэ была такая, казали, што перэдала, там шэпчэць и перэдала маць, а як перэдала, гэто тайна. А ужэ як не перэдасць каму-то, то цяжко ўмираець [БВВ] (Оранчицы).

\section{Покойник в доме}

1. [Как клали покойника в доме?] Ў красный угол укладывали, к абразам галаваю, так ляжаў пакойник, а зараз ставяць хто как. [Ставили ли для покойника еду и воду?] Возьле пакойника у нас ставили тольки сьвечку адну, и ана гарэла, ў стакан з зярном ставили, а ужэ воду и кусочак хлеба ставили, як вячэраць [садились], паминальная называецца у нас вячэра па пакойнику. [Ставили воду или водку?] Кажуць, што па-настаяшчэму трэба наливаць воду, кались наливали воду, а зараз ужэ тожэ хто воду, хто водку, ложаць кусочак хлеба, зараз дабавляюць и калбасу, и што хочэш, а после думаюць, куда яго падзець... Скацине якож нэдобрэ аддаваць, ўот такэе. [Закрывали ли зеркала?] Да, ўси зеркала, серванты, буфеты, ўсё закрывали простынью и часы астанавливали, и зараз так. Ну, чтобы ниякий недобрый [дух] не всялился, штоб ўсё было спакойно, цихо [РЕИ] (Ровбицк). тяжело умирать. Женщине вынимали доску из потолка в доме, она не могла умереть, лежала трое суток и говорила: «Сын, дай мне руку, дай мне руку». А он не захотел, и она тогда долго умирала и ей выдирали потолочную доску [РЕИ] (Ровбицк).

7. Чтобы облегчить агонию ведьме, разбирали потолок, это точно. Она обязательно должна передать свои знания, чтобы легче умереть. Это делалось наедине, без посторонних, если она хочет передать, это делалось тайно... У нас тоже была такая, говорили, что искусство заговаривать ей передала мать, а как она передала, это тайна. А если не передаст кому-то, то тяжело умирает [БВВ] (Оранчицы).

1. Покойника укладывали в красный угол, головой к иконам, так раньше лежал покойник, а теперь ставят кто как. Возле покойника у нас ставили в стакане с зерном одну горящую свечу, а воду и кусочек хлеба ставили, когда садились поминать, у нас называется поминальный ужин, поминки. Говорят, что правильно наливать воду, раньше наливали воду, а теперь кто воду, кто водку наливает, кладут кусочек хлеба, а теперь добавляют и колбасу и что угодно, а потом думают, куда это девать... Скоту нехорошо отдавать, вот такое. Да, закрывали простыней все зеркала, серванты, буфеты, все закрывали и часы останавливали, и теперь так делают. Это для того, чтобы не вселился никакой недобрый дух, чтобы все было спокойно, тихо [РЕИ] (Ровбицк). 
2. Пакойник ляжыць, и он доўжэн ляжаць цэлую ноч и яшче днём, и ўсё врэмя далжна гарэць сьвечка. Ставили грамничные пачаму-то. [Нужно ли было читать молитвы рядом с покойником?] Пастаянно, и песьни [церковные] пели, а щас ужэ их нет, а сядзели рядом с покойником. [Где клали покойника?] На покуць, там абраза далжны быць, ў кутку, голавой на покуць, пад абраза галавой; адзёжки [в гроб] ложуць сьменные, запасные, коб было во что перэадецца, но есьли што-то забудуць, то кажуць, той сьниўса, трэба заехаци на кладбишчэ, прыкапываюць. <..> [Ставили ли еду и воду для души?] Хлеб ложаць, соль ложаць, в зярно вставляюць сьвечку, вот гэто стаиць. [Что потом делали с этим хлебом?] Сьвиням и курам [отдавали]. Лучше всего курам, баба казала, коб куры паклевали. Пцичкы прылецяць там. < ..> А ешче я знаю, што баба акурывала пакойника, сьвятое зелле абязацэльно паджыгали и акурывали, ўсё акурывали. [Какими травами?] Гэто, каторое на Спленне [Успение]. На Спленне же цьветы хранят, баба, помню, пацёрла, запалила, и труну, и веко, всё [окуривала]. <..> [Кто приходил читать по покойнику?] Хто ўмее, хто мог чытаць, были людзи такие ў дзяреўне, были такие сьвятые, каторые паюць. [Что им за это давали?] Кликали на вячеру, больше ничэго. [Сколько они читали?] Есьли такие людзи близкие, ани цэлу ноч магли чытаць; ёсь, да двянаццаци пасядзяць и уходзяць, а есьли челавек близкий, то ўсю ноч магли: так дагаварицца, што по очеради. Адзин да двенаццаци, другой патом. [Что еще делали в доме покойника?] Зеркала закрывали, часы астанавливали. Патом яго завязли [увозят хоронить], часы заводзюць, жызнь пашла. Жызнь астанавилась, [когда умирает человек],
2. Покойник в доме должен лежать целую ночь и еще день, и все время должна гореть свечка. Ставили почему-то громничные свечи. Возле покойника читали молитвы и пели церковные песни, сейчас уже этого нет, и сидели люди рядом с покойником. Покойника клали на покути, там, где в углу иконы, головой под образа; в гроб клали сменную одежду, чтобы ему было во что переодеться, а если что-то забудут, то говорили, что покойник снился и просил, тогда нужно заехать на кладбище и прикопать эту вещь на его могиле. Для души ставили хлеб и соль, свечку вставляли в посудину с зерном, и это стояло. Потом этот хлеб отдавали свиньям и курам, лучше всего курам, чтобы они его склевали вместе с другими птицами, которые могут прилететь. А еще я знаю, что бабушка окуривала покойника освященными на праздник Успения травами, обязательно их поджигали и все окуривали. Травы и цветы, осященые на Успение, обычно сохраняют, помню, бабушка их потерла и зажгла, и гроб, и крышку, все окурила. Читать по покойнику приходили те, кто умеет это делать, такие люди были в деревне, были такие набожные, которые поют. За это их приглашали на поминки, а больше ничего не давали. Близкие люди могли читать всю ночь, некоторые сидели и читали только до двенадцать, а если человек близкий, то могли читать всю ночь, договорятся и читают по очереди. Один до двенадцати, другой после. Когда покойник в доме, закрывали зеркала и останавливали часы. Когда умершего увозят хоронить, часы заводили, это означало, что жизнь снова пошла. Когда человек умирает, жизнь остановилась, должно все остановиться. А про зеркала я спрашивала бабушку, почему их надо закрывать и она говорила: «Он будет через зеркало к тебе приходить, будешь смотреть в зеркало и будеш его все время видеть, поэтому нужно зеркала закрывать». Говорили, 
далжно ўсё астанавицца. А зеркала... бабу спрашывала, чаму зеркала закрываць, ана казала: «Бо он будзець чэраз зеркало до цябе прыходзиць, будзеш глядзець ў зеркало, и будець табе ўсё ўремя он ў зеркале, трэба зеркало закрываць». Люстро казали, люстро закрыли, патаму что ён будзе прыходзици. Не нада гэтаго [БВВ] (Оранчицы).

3. Умывали и зарэ, ужэ адзёжка, ужэ ляжыць гатовая, а тады як помню, челавек умираець, и сразу... пакойник ляжыць, и шыли [одежду]. Два часа нада ждаць, пака узнаш, што ўмёр; грэецца вада, тапили [печь], грэюць воду, пакойник ляжыць, и швец ужэ... и шыець ей нарады, таму пакойнику, мужчынам йетая, а жэншынам полныя [наряды]: и кофты, и йеты... хоць старушка, а ёй не было, чи нельзя было [заранее готовить одежду на смерть], [женщина] ражает дзецей, ражает, нельзя ничого загатавливаць заранее, не знаю... не помню. Но помню, што прыводзяць ў хату партниху, ана па-быстраму шьець, и зразу мыюць, адзяваюць. А зараз тое палажыла, панравилася, начала насиць, другое... Пака сьмерць идзець, я меняю ўсё нарады... [смеется]. Ну, адзели, клали на покуци, ўсё казали, красный йетат угал, иконы там и лампадки кругом, и там туды [кладут]. Плакают, независимо, какого возраста умираець челавек, но так вси прыголо́шывали, як ужэ [сейчас] никто не прыгала́шывае. То не жалеюць < ..> a то, хто большэ всех крычыць, тады ужэ [значит, что] харошый [был] пакойник. [Ставили ли свечу возле покойника?] Сьвечки, пастаянно сьвечки, были васкавые самые, сабиралися жэншыны, не помню, коли, можэ в Вяликий пост перад Пасхаю, сьвечки бальшые из воску делали, сами жэншыны сабиралиса, качали. [Какие это свечи: громничные или чет- закрывали зеркало, потому что иначе он будет приходить. Не нужно этого [БВВ] (Оранчицы).

3. Мыли покойника, теперь уже лежит для него готовая одежда, а раньше, я помню, когда человек умирает и покойник лежит, шили ему новую одежду. Два часа нужно ждать, чтобы убедиться, что человек умер, тогда топили печь, грели воду, и портной шьет ей наряды, тому покойнику, мужчинам эти, а женщинам полные комплекты: и кофты, и остальное... даже у старушек не было одежды на смерть, а может, нельзя было ее заранее готовить, женщины рожают детей, нельзя ничего заготавливать заранее, не знаю, не помню... Но помню, что приводили в дом портниху и она шила по-быстрому, и сразу покойника мыли и одевали. А сейчас я положила одно, потом оно понравилось, начала носить, положила другое... Пока смерть идет, я все наряды меняю (шутит)... Ну, одели покойника, кладут его на покуть, в красный угол, там кругом иконы и лампадки. Плакали, голосили по умершему вне зависимости от его возраста, но так голосили, как теперь никто не голосит. Если не голосят, то не скорбят <..> а если сильно кричат, это значит, что хорошим человеком был покойник. Возле покойника постоянно стояли восковые свечи, собирались женщины, не помню, может в Великий пост перед Пасхой и делали из воска, катали большие свечи. Это обычные свечи из воска, громничные это другие, их освещали в церкви и приносили оттуда, а так делали свои. У меня сохранилось 
верговые ${ }^{1}$ ?] Абычные сьвечки из воску, а грамничные, это ж в цэркви брали [и] асвяшчали, а так сваи гатовили. У мяня нескалько сахранилось ат прабабушки, я забра́ла. Ставили в баночку чи в якую пасудину, насыпали зярна и туды ставили сьвечки, падсьвечников тады не було. [Ставили ли воду для покойника?] Воду не ставили, коли жара́, то ставили, коб сахранился, крапивой абкладывали тожэ, вроде сахраняецца лепшэ. [Клали ли хлеб для него?] А хлеб абязацэльно, хлеб и соль там, где сьвечка горыць на тумбачке, ци столик, и стаяло там ўсё. Воду ставили сьвянцоную, асвяшчоную, крэшчэнскую ставили. Как бацюшка прыязжаў атпяваць ў цэркву, атпяваў яго, тагда той вадою [кропил]. [Поминальную] кашу ж варыли в той дзень, кады пахаронюць. Абычна должэн пакойник хоць адну ночку пераначаваць. [Почему?] Ну, паследняя ночь коб в даму была. <..> [Приходили ли читать по покойнику?] Чытали, пачытаюць тые самыя малитвы, прымерна нехто. У нас адна ў Шэрашо́во, певчая работала ана, прыяжжала, ў дачки́ жыла, тагда нескалько пакойникоў умирало, вона ужэ йим чытае, ужэ и ей за ето што-то плацили. Старовойский сельсавет... у нас там умирали, я была там, то там сядзяць цэлый дзень и цэлу ноч, стаит столик и канфеты, вада газированая, ужэ купляеш им, фсё уурэмя то паюць песьни йетыя набо́жныя, то чытаюць и цэлую ноч начуюць. Не как у нас сидзяць каждый пра сваё гаворыць, а там ўсё пасвяшчано пакойницэ [ПЛВ] (Хорева). несколько таких свечей от прабабушки, я их забрала себе. Свечи ставили в баночку или другую посудину с зерном, подсвечников тогда не было. Воду для покойника не ставили, но если была жара, то это делали для сохранности тела, могли еще обкладывать его крапивой, от этого тело вроде лучше сохраняется. Обязательно возле умершего клали хлеб и соль на тумбочке или столике рядом с горящей свечой. Воду ставили освященную, крещенскую. Батюшка в церкви на отпевании кропил умершего этой водой. Поминальную кашу варили в день похорон. Покойник обычно должен переночевать хотя бы одну ночь в своем доме. Люди приходили читать молитвы по покойнику. У нас одна женщина, певчая из церкви, приезжала из Шерешево к дочке и жила у нее, тогда умерло несколько людей (в Хоревах), она по ним читала и ей за это платили. Старовойский сельсовет... у нас там умирали, я там была, и там сидят возле умершего целый день и целую ночь, стоит столик, на нем конфеты и вода газированная - их покупает хозяин для этих людей, они проводят возле умершего целую ночь, читают молитвы и поют религиозные песни. Это не как у нас сидят - каждый про свое разговаривает, а там все посвящено покойнице [ПЛВ] (Хорева).

\footnotetext{
${ }^{1}$ Свечи, освященные в четверг перед Пасхой, в ряде случаев функционально изоморфные громничным свечам в погребальной и поминальной обрядности.
} 


\section{Запреты при покойнике}

1. [Можно ли здороваться, когда приходишь в дом, где есть покойник?] Нет, гаварыли, што няльзя здаровацца. Раньшэ прыходзили, то проста кланялись и шли с малитвай к пакойнику, гэта я знаю добрэ. Зараз хто да цэркви ходзиць, то «слава Богу» кажэ, а ни «здраствуйцэ», ни «добрый дзень». [А когда уже можно здароваться?] Як пахаваюць. [Можно ли закладывать что-либо на хранение, когда покойник в доме?] Канешно. Гэто нихто... Не сказаць, што гэто быў який праздник, не робяць, не закладываюць, ну па крайней мере ў доме и близкие родственники. <..> [Можно ли подметать, когда в доме покойник?] Нет, не мели. Йесьли пакойника выносяць с хаты, тады замятаюць, но замятаюць ў вугол, сыпали зярно [по дому], и ужэ гэтый мусор выкидываюць назаўтра [РЕИ] (Ровбицк).

2. [Можно ли здороваться в доме умершего?] Гавараць, што не можна. [А можно ли заготавливать впрок что-либо?] Нет, я дажэ не только в доме [не делала], а в сяле, гавараць, што и садзиць ничого няльзя, патаму что не будзе, не садзици, не йетаго... Не сеяць в тот дзень, ужэ як ў сяле пакойник, ничого не сей. Дажэ, гавараць, и мыцца самому не можно. [Когда уже можно?] Ну, панясуць, вынясуць с сяла, тады можна мыцца [ПЕА] (Клепачи).

\section{Покойницкие предметы}

1. [Что делали с водой, в которой мыли покойника?] С гэтым, кались мама казала, што гэто выливали туда, где нихто не ходзиць, где не ступае нага. Да, жэлацэльна, штоб и сонцэ не свецило [там] и нихто не хадзиў. И мыло под який куст закопвали, и трапки. А нашчот тых адзёжэк... не уничтажали ўси,
1. Приходя в дом, где есть покойник, здороваться нельзя. Раньше приходили, просто кланялись и шли с молитвой к покойнику, это я хорошо знаю. Теперь те, кто ходят в церковь, говорят (заходя в такой дом) «слава Богу», а не «здравствуйте», и не «добрый день». Здороваться можно, когда покойника похоронят. В доме, где есть покойник, нельзя закладывать что-нибудь на длительное хранение (напр. капусту, консервировать - прим. соб.). Не сказать, что это было как в праздник (запрет на работу), но этого не делают, не закладывают, ни в этом доме, ни в домах ближайших родственников. В доме покойника нельзя подметать, в крайнем случае заметали в угол. Когда покойника выносят из дома, то тогда выметают и мусор, и зерно, которое было рассыпано по дому, и все это назавтра выкидывают (в день похорон) [РЕИ] (Ровбицк).

2. В доме умершего нельзя здороваться, в нем и во всем селении нельзя заготавливать что-то впрок, говорят, что и сажать ничего нельзя, иначе оно пропадет. И сеять нельзя, если в селе покойник. Даже, говорят, нельзя мыться. Когда умершего вынесут из села, тогда можно помыться [ПЕА] (Клепачи).

1. Мама говорила, что воду, в которой мыли покойника, нужно выливать туда, где никто не ходит, где не ступает нога. Да, желательно, чтобы и солнце там не светило и никто не ходил. И мыло под какой-нибудь куст закапывали, и тряпки (которыми мыли). А насчет одежды умершего... не уничтожали все, хорошие 
трэба была насиць другим людзям, стоящее трохи [РЕИ] (Ровбицк).

2. Я очень многа пакойников мыла, и тую воду трэба вылици там, где людзи не ходзюць, ци за хлеў, закапаци тую воду там, мыло там жэ. [Что делали с одеждой покойника?] Палили, ци перадавали, каму што. [Что делали с его постелью?] У нас бяруць, вынясуць, паляжыт, перасушыш, перабьеш [КОИ] (Клетное).

3. Наабарот, ўсё павыкидала, я ўсё папалила [постель покойника]: и падушку, и адзяяло, я вынесла уусё на поле и сьпалила. [Что делали с одеждой?] Тожэ паляць, и тюфяка што пад им было, ўсё спалила, и тая адзёжа, што он служыў, хадзиў; только астались плашчы ат даждю [CЕВ, ПЕА] (Клепачи).

4. Вокна и дзьверы закрывали [когда покойник в доме], потому что есьли воздух, то он [покойник] почарнее, пацямнее; лажыли на пол [покойника], мыли, адзявали, а тую воду выливали... Нэ зразу яе выливаюць, выносюць, вот ана стаиць; кагда пакойника ужэ вынесуць, [тогда выливали], и адзежду закапывали туды. Толька выливали и адзежду закапывали тую, в каторой он умираў, в якое-то место, где-то там [БВВ] (Оранчицы).

\section{Вынос}

1. [Как выносили покойника из дома?] Нагами [вперед]. Як, прыменно, ў хату нясуць, то трэба нясци галавой ўперод, а як выносюць - нагами. <...> Як баяцца пакойника, и як ужэ яго забяруць, то сваих дзяцей трэба садавиць на тэе место, где гроб стаял [КОИ] (Клетное).

2. [Нужно ли садиться на место, откуда только что вынесли гроб?] Гэто, кажуць, коб не баяцца, коб не баяцца пакойника, забяраюць жэ... Хто астаецца вещи другим людям еще были нужны, их носили [РЕИ] (Ровбицк).

2. Я очень много покойников мыла и эту воду нужно выливать там, где не ходят люди, может, за хлев, и закопать эту воду и мыло. Вещи покойника сжигали или отдавали другим. Постель покойника выносили из дома, пересушивали, выбивали [КОИ] (Клетное).

3. Наоборот, я все выбросила, все сожгла: и подушку, и одеяло, я вынесла все на поле и сожгла. Одежду тоже сжигают; и тюфяк, на котором он лежал, я все сожгла, и ту одежду, которую он носил при жизни, когда служил (в армии), остались только дождевики [СЕВ, ПЕА] (Клепачи).

4. Когда покойник в доме, закрывали окна и двери, потому что от воздуха тело потемнеет, почернеет; покойника клали на пол, мыли, одевали, эту воду выливали... Ее выливают не сразу, сначала ее выносили из дома и она стояла (где-то на подворье); когда покойника унесут хоронить, ее выливали и туда же закапывали ту одежду, в которой он умирал. В какое-нибудь место, где-то там [БВВ] (Оранчицы).

1. Покойника выносили из дома ногами вперед. Если несут в дом, то нужно нести головой вперед, а если выносят - то вперед ногами. Когда гроб с покойником снимают с лавки, на это место нужно сажать своих детей, если они боятся покойника, чтобы перестали бояться [КОИ] (Клетное).

2. На лавку, где стоял гроб, садились, чтобы не бояться покойника. Тех, кто будет жить в этом доме, заставляли сесть на то место, где стоял гроб, чтобы они не боялись. О переворачивании табуреток, 
ў хаце, коб не боязно быци, застаўляли сесць на тое место, гдзе стаяла труна. [Нужно ли перевернуть табуретки, на которых стоял гроб?] Не, не было́ [ПЛВ] (Хорева).

3. [Переворачивали ли скамейки, с которых сняли гроб?] Пераве́рнуць, [сначала надо] сесци, а патом перавярнуць. [Для чего это делали?] А для таго, штоб не баяўса, каб не баялася. И их [скамейки] перавярнуў, и сыплюць жыто йешчэ ў хату, як хто астаецца жыць, каб жыў чалавек [РНП] (Юндилы).

4. [Можно или нельзя спать на постели покойника?] Гаварыли, што трэба спаць там, гдзе ляжаў пакойник и гдзе ўмираў, што падымаюць пакойника, выносюць с хаты - и там хоць дочка, ци сын [спит]. Хто астаецца, трэба была хутчэй сесци на тыю лаўку, шоб род не разойшоўса, штоб ўсе были дома, шоб ўсё вялось, карочэ [РЕИ] (Ровбицк).

5. [Садились ли на то место, откуда только что вынесли гроб?] Эта садзяцца маладыя, каб не баялись. Ложаць пакрывало [под гроб], тады снимаюць, пакрывало на пол скидаюць сразу. Вынесли. Астаецца жэншчына, [она] сразу мыець палы, ўсё мыець, нада вячэру зрабиць, людзей пакармиць. <...> [Делали ли что-нибудь особенное на пороге при выносе?] Зярно сыплюць. Проста вынясли, [а потом] такая жэншчына ўжэ ў возрасце пасыпала зярна ў хаце [CЕВ, ПЕА] (Клепачи).

6. [Сыпали ли житом на пороге при выносе?] О, точно, сыпали. Хату пасыпа́ли ў нас, як выносили ўжэ. [Закрывали ли окна и двери сразу после выноса?] Ну, закрывали, помню, патом аткрывали вокна, як мы прыезжали [с кладбища] [БВВ, ПТФ] (Оранчицы). на которых стоял гроб, не слышали [ПЛВ] (Хорева).

3. На скамейки, где стоял гроб, сначала нужно сесть, а потом их перевернуть; это делали, чтобы не бояться покойника. Перевернули скамейки и посыпали зерном полы в доме, чтобы в нем оставалась жизнь, чтобы жил человек [РНП] (Юндилы).

4. Говорили, что на том месте, где умерший спал и где он умирал после похорон должен поспать сын или дочка. Оставшиеся родственники должны были скорее сесть на ту лавку, с которой сняли гроб, чтобы род не разошелся, не прервался, чтобы все были дома, чтобы все велось, короче [РЕИ] (Ровбицк).

5. На лавку, где стоял гроб, садились молодые, чтобы не бояться покойника. Под гроб стелили покрывало, а когда (при выносе) гроб снимают, покрывало сразу же сбрасывают на пол. В доме после выноса остается женщина, она сразу моет дом и полы, надо еще приготовить поминки, покормить людей. На пороге при выносе сыпали зерно, женщина в возрасте просто посыпала зерном пол в хате [CЕВ, ПЕА] (Клепачи).

6. На пороге при выносе сыпали зерно, дом посыпали у нас, когда выносили (покойника). Закрывали окна и двери, помню, потом открывали окна, когда приезжали (с кладбища) [БВВ, ПТФ] (Оранчицы). 


\section{Процессия}

1. [Можно ли спать, когда мимо несут покойника?] Дажэ нясуць пакойника, дажэ есьли хто ў хаце спиць, коб ён не спаў - трэба разбудзиць. [Останавливались ли по дороге на кладбище?] Да, раньшэ ж не́сли ўсех [на руках], мянялися жэ хлопцы, но в концэ [села] ўсегда выставляли лаўку ци табурэтки и ставили, и хто не успеў прасцицца, падхо́дзили да яго, прашчаецца, и ужэ тады далей не́сли. А зараз машынай, но астанавливаюцца у нас там, [где] хрэст такий стаиць. Хто хочэт прашчаецца и проста пастаяць. [Посыпали ли дорогу еловыми ветками?] Пасыпали, раньшэ кидали, рубали сасну, можэ ат автаритэту умэршэго, хто цвятами [РЕИ] (Ровбицк).

2. И спаць нельзя [когда мимо дома несут покойника], падымаюць, [если] дзиця малое, так падымаюць. [Где останавливалась процессия?] Тольки ля крэста. Пастаяць да папрашчалися, хто хочэт папрашчацца, и паехали. [Бросали ли ветки на дорогу?] Гэто кагда чалавек маладый умирае, ўот с гэтай хаты маладый чалавек на матацыкле забиўся, хлопец, брасали цьвяты, пакуда яго данясли да храста и далей пад горку брасали, а другим людзям, хто дажывае... [нет] [CЕВ, ПЕА] (Клепачи).

3. Няльзя, няльзя, дзецей паднимаюць, няльзя спаць, [когда] с пакойникам праходзюць, кагда мимо, коб не спаў. [Почему так?] Баба казала, не абъясняла: «Не трэба, коб спали дзеци и взрослые, нада будзиць». Я ешчэ пытала: «А чаго?» - «О, то хутка заснёш вечным сном». [Где останавливалась процессия?] Возле хрэста тольки астанавливались; есьли где-то йешчо, напрымер, человек жыў в адном месце, патом перэселиусся ў другое, в том старом месце астанавливались, гдзе он раньше жыў.
1. Когда мимо дома несут покойника, нельзя спать, а если кто-то спит, то нужно разбудить. Раньше гроб несли на руках и парни менялись, но в конце села всегда выставляли лавку или табуретки, там гроб ставили и кто не успел проститься, подходили, пращались и гроб несли дальше. А теперь (везут) на машине, но останавливаются там, где стоит крест. Кто хочет, прощаются и просто постоят. Раньше дорогу посыпали срубленными ветками сосны или цветами, может, это зависело от авторитета умершего [РЕИ] (Ровбицк).

2. Нельзя спать, когда мимо дома несут покойника, будят, и маленьких детей будят. Процессия останавливалась возле креста. Постоят и попрощаются те, кто хочет попрощаться, и поехали (дальше). Дорогу посыпали цветами только молодым умершим, вот из того дома парень погиб на мотоцикле, ему бросали цветы на дорогу, пока донесли до креста и дальше под горку, а тем, кто (свой век) доживает, (старым не бросали) [CEВ, ПЕА] (Клепачи).

3. Нельзя спать, когда мимо проходят с покойником. Бабушка говорила, не объясняла: «Нельзя, чтобы спали дети и взрослые, нужно будить». Я еще спрашивала: «Почему?» - «О, скоро заснешь вечным сном». Процессия останавливалась только возле креста (придорожного), еще, если, например, человек жил в одном месте, потом переселился в другое, останавливались на старом месте, где он некогда жил. Навстречу погребальной процессии идти нельзя. Если несут покойника, а навстречу идет человек или едет машина, то нужно обяза- 
[Можно ли идти навстречу погребальной процессии?] Нельзя ици навстрэчу. Пакойника нясуць, навстрэчу челавек идзёць, машина, абязацэльно астановицца, пака он [покойник] не прайдзёт. Такое было и щас [соблюдается] [БВВ, ПТФ] (Оранчицы).

4. Есьли па дароге едзеш и храсты [стоят], абязацэльно астанавливаюцца [с гробом], и прыменно, мой муж работал учыцелем... выязжали, стали коло школы, учэники ждали, праважали. [Вешали ли полотенце на крест, когда возле него останавливалась погребальная процессия?] На той хрэст, гдзе стаиць на улицэ, астанавливалиса и вешали. Хто вешал хрэста, хто ленту завьязывали, на пахаронах. [Можно ли ехать навстречу процессии?] Казали, што йето нехарошый чэлавек паехаў. [Почему?] Не уважаець [ПЛВ] (Хорева).

5. [Встречают ли души прежде умерших погребальную процессию у кладбища?] Гаварыли и гаворяць, што етые вьсе душы ўстречаюць ў варотех ужэ пакойника [КОИ] (Клетное).

6. Ну, гавараць, што ўстрэчаюць, што ўсе, хто там е, ўсе яго ўстрэчаюць. Адна жэншчына не 3 нашэй дярэвни, там, где я рабила некали, рассказывала: у нас адна бабка да ўсих, да ўсих на пахарана хадзила, и ў сваёй дярэвни, и радом тожэ шла. Да прышоў ўнук, да й гавориць: «Бабушка, иди, там памёр хто-та, идзи туда». И тая бабушка тут же пашла туда глядзець, хто памьёр, а там сабака памьёр. Ў том дварэ. И уже як ана сама памерла и уже каму-та, ти ўнук той гаварыл, ти хто з радни, што, гаворыць, прыснилась тая бабка и кажэ: «Ой, людзи, але мяне ўсе-ўсе-ўсе ўстрэчали, дажэ и сабака сьвечачку дзержаў мне». Да. «Дажэ и сабака сьвечачку дзержаў». А тельно остановиться и подождать, пока покойник не пройдет. Такое было раньше и сейчас соблюдается [БВВ, ПТФ] (Оранчицы).

4. Если по дороге идет погребальная процессия, обязательно останавливались с гробом возле придорожных крестов; мой муж работал учителем... выезжали, встали возле школы, там ждали его ученики, которые его провожали. Во время следования процессии останавливались возле придорожных крестов и кто вешал на них крест, кто ленту завязывал. Навстречу процессии, говорили, мог ехать только нехороший человек, он не уважает покойного [ПЛВ] (Хорева).

5. Говорили и говорят, что души всех прежде умерших встречают в воротах кладбища нового покойника [КОИ] (Клетное).

6. Говорят, что все души, кто там есть, встречают покойника. Одна женщина не из нашей деревни, а там, где я когда-то работала, рассказывала: у нас одна бабка ходила на похороны всех, всех провожать, и в своей деревне, и рядом тоже шла. И пришел ее внук и говорит: «Бабушка, иди, там кто-то умер, иди туда». И та бабушка пошла смотреть, кто умер, а там умерла собака, в том дворе. И когда она сама умерла, то, или внук ее рассказывал, или кому-то из ее родни она приснилась и говорит: «Ой, люди, как меня все-всевсе встречали, даже собака держала мне свечку». Да. «Даже собака держала свечку». А внук посмеялся над ней, 
ўнук пасьмеяўся з яе што хадзила, каже: «Идзи, баба, тамо умьёр нехто». [В каком месте это было?] Саседние дяревни, Байки, Манчики, как на Ружаны ехаць. (Клепачи) [CEB].

\section{Погребение}

1. [Что бросали в могилу?] Ўси кидаюць зе́млю па тры горсци. [А деньги?] Деньги, это мне мама кались казала... як мая мама ўмирала, так казала, штоб палажыли ў карманчык чы ў руку капейку: «Ты мне палажы хоць скольки». И палажыла ей там мелачы, платочак який. А у нас тут тады сьвяшчэнник новый, прышоў сюда и як убачыў, што там тые капейки, и як стаў крычаць: «Што вы робице, што? Ваша мама там будзе на тралебусе езьдиць?». А я их аставила. Мне мама так казала. И зараз так кладуць. И бяльё ложаць [в гроб], и майку мужчыне, трусы, сарочку там, палаценце. Тожэ крычаў сразу [священник]: «Што у вас там, ў баню хадзиць будзе?» А я кажу: «Не знаю, хто будзет хадзиць там» [РЕИ] (Ровбицк).

2. [Покрывали ли гроб скатертью?] Да, так само, и рабыли гэтые труны, и засцилали такие красивые. Каб не голо было, каб красивее было. Пакрывали, кали нясуць, а як занясуць, апускали [в могилу], ужэ так гэтае пакрывало снимали. [Что с ним делали?] Да хаты забирали. <..> Мая маци восямдзесят дзевяць гадов, кажэ: «Мяне каб наслали, - наткали некали шэрсцяные такие [покрывала], - каб накрыли гроб, я не хачу, штоб на мяня пясок сыпаўса, а каб на гэтае пакрывало сыпаўса. Я не хачу. А то ў вочы будзець песок сыпацца, трэба, коб накрыли». Это маяго зяця, гдзе яго родина - Зэльвенский район, Гродненская обласць. Не нашэй обласци, нет, там так дзелаюць. Харанили маяго свёкра, <...> ана [свекровь] накрыла, и засыпали с тым пакрывалам гэтым что она ко всем ходила, говорит: «Иди, баба, там кто-то умер». Это было в одной из соседних деревень: Байки, Манчики, по направлению к Ружанам (Клепачи) [CEB].

1. В могилу все кидают по три горсти земли. А деньги, мне мама, когда умирала, говорила, чтобы ей положили или в руку, или в карман копейку: «Ты мне положи хоть сколько». И я положила ей там мелочи, в платочек. А у нас тут тогда священник был новый, пришел сюда и увидел, что там эти копейки, и как стал кричать: «Что вы делаете, что? Ваша мама там на троллейбусе будет ездить?» А я их оставила. Мне мама так наказала. И сейчас так кладут. И белье кладут в гроб, мужчине майку, трусы, сорочку, полотенце. Тоже сразу кричал священник: «Что он у вас там, в баню ходить будет?» А я говорю: «Не знаю, кто будет ходить там» [РЕИ] (Ровбицк).

2. Гроб покрывали скатертью и делали эти гробы, и застилали такие красивые. Чтобы не голо было, чтобы красивее было. Покрывали, когда гроб несут на кладбище, а когда опускали в могилу, тогда это покрывало снимали и забирали его домой. $<\ldots>$ Моей матери восемьдесят девять лет, она говорит: «Мне чтобы покрыли - некогда ткали такие шерстяные покрывала - чтобы накрыли гроб, я не хочу, чтобы на меня песок сыпался, пусть лучше на это покрывало сыпется. Я не хочу. А то в глаза будет песок сыпаться, нужно, чтобы накрыли». Это там, где родина моего зятя, Зельвенский район, Гродненская область. Не в нашей области, нет, там так делают. Когда хоронили моего свекра, свекровь накрыла гроб и его засыпали вместе с этим по- 
гроб ў магилу, а бацюшка стаиць и гаварыць: «Зачэм, гэто лишнее, есьли ано вам не надо, так лучше нишчым атдайце, чым вы яго закапываеце в землю». Но нихто яго не знимаў, як павесили, и засыпали, и ўсё. $<\ldots>$ [К чему дождь на похоронах?] Ну, на похаранах не только родственники плачуць, но и Бог тожэ [CEВ, ПЕА] (Клепачи).

3. [Стелили ли скатерть на гроб на похоронах?] Зараз сцелюць ци пакрывало, ци скацярць, але бацюшка не разрэшае, кажэ, што ни нада, нашто, чтобы ано гнило́, труна хутчэй гнила [РНП] (Юндилы).

4. [На чем опускали гроб в могилу?] Ну, тады йяшчэ ручники были, доўгие. Апускаюць и астаўляюць там. [Бросали ли деньги в могилу?] Ки́даюць капейки, но зараз у нас дачка была, ки́дала капейки, смяюцца: «Ци дай нишчаму, чым ты ки́даеш ў землю». <..> [Можно ли оставлять выкопанную могилу на ночь?] Ой, не, нельзя. У мяня сын на Урале самый меньшый, и мы дали яму телеграму, думали, што прыедзець [на похороны отца], а ждали, ждали, а людзей сабралось много, даже прэдседацель калхоза и главврач, каторый лячыў маяго мужа. И ждали, ждали... и не знали, што рабици, сказали, давай на кладбишчэ апусцим [гроб] и не закрываем [не будем закапывать], так аставиць, патом будзем даставаци... а дома нельзя астаўляць. А долу нельзя астаўляць. Не рэкамендуецца капаць дол, штоб начаваў пустой [ПЛВ] (Хорева).

\section{Мемориальные сооружения}

1. [Что ставили на могилу на похоронах?] Крэст. А памятник чэрэз год ставицца, а давней проста крэсты. [Куда девали старые кресты?] Меняли, канешно, сколька ж той крэст, в зямле згние. Прыменно, памятник ставишь, то выно́- крывалом в могилу, а батюшка стоит и говорит: «Зачем, это лишнее, если оно вам не нужно, лучше нищим отдайте, чем вы его закопаете в землю». Но никто его не снимал, как накрыли, так и засыпали, все. Дождь на похоронах, это не только родственники плачут, но и Бог тоже [CEВ, ПЕА] (Клепачи).

3. На гроб стелят сейчас или скатерть, или покрывало, но батюшка не разрешает, говорит, что не нужно, зачем, от этого гроб быстрее гниет [РНП] (Юндилы).

4. Ну, тогда еще длинные полотенца были, на них опускали гроб в могилу и их оставляли там. Бросают в могилу и копейки, но сейчас у нас была дочка, на похоронах бросила в могилу деньги, люди смеются: «Лучше дай нищему, чем ты их бросаешь в землю». Заранее выкопанную могилу на ночь оставлять нельзя. У меня сын младший на Урале, умер отец и ему дали телеграмму, думали, что приедет, ждали, ждали, собралось много людей, даже председатель колхоза и главврач, который лечил моего мужа. И ждали, ждали... и не знали, что делать, сказали, давайте гроб в могилу опустим и не будем засыпать, а потом достанем... дома нельзя оставлять. Не рекомендуется копать могилу, чтобы она ночевала пустая [ПЛВ] (Хорева).

1. На похоронах на могилу ставили крест, памятник устанавливали через год, а раньше ставили только кресты. Сгнившие кресты меняли на новые; когда ставили памятник, то старый крест выносили - а они были без дощечек с 
сили [старый крест], ани жэ были без дошчачак, то выносили и ко́ла забора ставили. У каго няма хазяина, дзеци далеко, то брали цэлейшаго [из этих крестов], то ставили, мяняли, хто не даведал сваих. А зараз ужэ с дошчачками, то трэба жэ тую дошчачку скидаци... [ПЛВ] (Хорева).

2. Через год [ставили памятник], як пахароняць, крэста паставяць, магилку зробяць, и ўсё. А чаму посьле года ставяць [памятник], патаму что зямля садзицца, впадае, а за год ана ужэ никак не впадае, а так и памятник валицца, и грабница. [Что делали со старым крестом?] Ляжыць на магиле, пака сгние [CEВ, ПЕА] (Клепачи).

\section{Нечистые покойники}

1. [Где хоронили самоубийц?] На кладбишчэ, у нас харанили на адном кладбишчэ, но их харанили в атзельнам углу. А цэперь харонюць вмесце. [Если убьет гром, это хорошо или плохо?] Канешно плохо. Но хто гаварыл, что Богу угодный, Бог его прыбраў, а другие значыц, так загрэшиў, што не було кали памалицца, гром забиў. Клянуць: «Коб цябе гром забиў» [РЕИ] (Ровбицк).

2. [Если убьет гром, это хороший или плохой человек?] Кажуць, што той дастойный чалавек. [Он в рай пойдет?] Казали так [КОИ] (Клетное).

3. [Хоронили ли на кладбище утопленника?] Харанили и бацюшка атпявал. Гэто висельника [запрещено хоронить], а так [остальных] харонюць. $<\ldots>$ И давней я помню, ешчэ пацанкой была, як суша, рабили. Як хто самаубийца, висяльник, дак прабивали магилу и ляли туды воду. А сенни наливае ў бутылку и кидае, як хароняць, апусцяць тады [гроб], бутылачку [с водой броса- именами - и ставили возле ограды кладбища. Если у какой-то могилы не было хозяина (того, кто бы мог за ней присматривать), дети живут далеко, то тогда из этих крестов брали тот, что получше и ставили на такие могилы. А теперь кресты уже с табличками с именами и надо же тогда табличку снимать...[ПЛВ] (Хорева).

2. Через год после похорон ставили памятник, на самих похоронах делали могильную насыпь, ставили крест и все. А через год ставили памятник, потому что земля садится, а за год она уже усядется, иначе и памятник упадет, и все сооружения. Старый крест оставляли лежать на могиле, пока он не сгниет [CЕВ, ПЕА] (Клепачи).

1. Самоубийц у нас хоронили на общем кладбище, но в отдельном углу. А теперь хоронят всех вместе. Если человека убьет гром, это плохо. Но некоторые говорили, что это человек, угодный Богу, Бог его прибрал; а другие считали, что это грешник, так грешил, что некогда ему было помолиться, убил его гром. Даже так проклинают: «Чтоб тебя гром убил» [РЕИ] (Ровбицк).

2. Говорят, что убитый громом - достойный человек, он пойдет в рай [КОИ] (Клетное).

3. Утопленника можно хоронить на общем кладбище и батюшка его отпевал. Запрещено хоронить там только висельника, а остальных хоронят. <..> И раньше, я помню, когда я еще была подростком, во время засухи делали такое: пробивали могилу самоубийцы, висельника и лили туда воду. А теперь воду наливают в бутылку и кидают ее на похоронах самоубийцы в его могилу, когда в 
ли], каб не было засухи. [Где их хоронили?] Их харанили на краю моглиц, на мо́глицах не було́. На самом краю [РНП] (Юндилы).

4. [Где хоронили висельника?] На кладбишчы. Некали не харанили давным-давно, а зарэ няма ничого. Раньшэ и нехры́шчаных дзяцей на кладбишчэ не харанили, а сення ўсё аташло: и забитых харонюць, и нехры́шчаных харонюць, и втопленника таксамо. Были атдзельно [раньше такие могилки]. Сягодня всякие хароняць на кладбишчэ. <..> [А не говорили, что когда вешаются, случается буря?] Як вецер, [то говорили]: «Ой, нехто павесиўса, ужэ бура такая» [CEB, ПЕА] (Клепачи).

5. За кладбишчэм [хоронили висельника]. [Кого еще не хоронили на кладбище?] Самаубийц, хто павесиўса, хто травиўса, самаубийц у нас не харанили. [А утопленника?] Есьли случайно, то гэто можна, а хто знает, случайно чи не, но в наше врэмя ужэ всех [хоронят], их [раньше] и в цэрковь не вазили, и не атпевали. [А можно ли их поминать в церкви?] Нельзя ни в коем случае. Нихрэшчо́ных и самаубийц нельзя паминаць. Панимаеце, самаубийцу спустя год можно атпеваци, кагда целый год за них молишся, падаеш [милостыню], птичэк кормиш, людзей там канхветками угашчаеш. Яго можно атмалици и спусьця год ехаци да благачиннаго, и йето ўсё расказаць, и можно атмалиць и атпець патом. У нас атмаливали [вот как], дзевачка самаубийца, кинулася с мо́ста маладая... [Расскажите подробнее про птичек] Ну, йето гавараць, птички йето каб божыя, и людзи каторыя, чэм больше людзей паминаець имя, ну, даеш канхвету, угашчаеш: «Памалицесь». Ну, хто-то скажэ: «Царство нябесное», и ето ужэ будзець харашо для таго челавека. Чэм боль- нее опустят гроб, чтобы не было засухи. Таких покойников хоронили на самом краю кладбища, на самом кладбище не погребали [РНП] (Юндилы).

4. Висельника хоронили на кладбище. Давным-давно не хоронили, а теперь уже этого нет. Раньше и некрещеных детей на кладбище не хоронили, а сегодня все это отошло: и убитых хоронят, и некрещеных хоронят, и утопленников. Раньше такое кладбище было отдельно. Теперь на кладбище хоронят кого угодно. <..> Если сильный ветер, то говорили: «Ой, это некто повесился, такая буря» [CEВ, ПЕА] (Клепачи).

5. Висельников хоронили за кладбищем. У нас не хоронили на кладбище самоубийц, кто повесился, кто отравился. Если человек умер случайно, утопился, то его можно похоронить на кладбище, а кто знает, случайно или нет; но в наше время уже всех на кладбище хоронят, а раньше их и в церковь не возили, и не отпевали. Поминать в церкви некрещеных и самоубийц нельзя ни в коем случае. Понимаете, самоубийцу через год можно отпеть, если целый год за него молиться и подавать милостыню: кормить птиц и угощать людей конфетами. Его можно отмолить, а спустя год ехать к благочинному и все это рассказать, и можно отмолить, и потом отпеть. У нас так отмаливали девочку-самоубийцу, она спрыгнула с моста... Это, говорят, птички это божьи (создания), и чем больше людей поминает имя умершего, (тем лучше). Ну, угощаешь, даешь конфету, просишь: «Помолитесь». Ну, ктото скажет: «Царство небесное» и это будет хорошо для покойника. Чем больше угощаешь, чем больше они говорят «царство небесное», тем лучше для это- 
ше угашчаеш, чэм больше ани гавараць «царство нябеснае», то для яго там ужэ лучшэ. И чераз год благачинный даець дабро и бацюшка атпеваець. $<\ldots>[$ А если некрещеный ребенок умер?] Гэто очень было плохо, когда некрещёное ўмерло, для гэтаго рэбёнка плохо было́. Я знаю, кагда радзились дзеци и кагда ани были слабенькие, то старались хутчей-хутчей до крэста, коб не памерло. [Если все-таки умер?] Гэто ўжэ ничего не зробишь, гэто ужэ замо́ливали, хадзили ў цэркву малились за яго. [Где их хоронили?] На кладбишчэ, атдзельна не хоронили. [А не говорили, что оно там плачет и просит его окрестить?] Да, говорыли, говорыли гэто, что яно там плачэ, яго не пусцяць да других [ПТФ, БВВ] (Оранчицы).

\section{Последний покойник в селе}

1. [Сторожит ли последний покойник кладбище?] Да, это было, и казали, што ужэ смянил ужэ. Поки другий умирае, той сторожем там на моглицах [СЛЯ] (Клетное).

2. Гаворяць и зарэ гаворяць, вот хто, например, паследний, сённяшний пакойник, вот вон ужэ смянил яго [предыдущего] на дежурстве на варотах. На варотах стаяў да сих пор. Тут прыснилася, быў ў сяле пакойник, прыснилася мама и гавориць: «Пуйдем Колю ўстрэчаць ўсе, будем Колю устрэчаць» [РЕИ] (Ровбицк).

3. Вот как в сяле хто памьёр, и за им доўго нема [другого покойника], говорым, долго, гаворат, на пасту стаиць, што другого пакойника нема. А следуюшчый яго сменяець. Некоторые хутка, а некоторые доўго стаяць [ПЕА] (Клепачи).

\section{Возвращение назад}

1. С кладбишча [когда возвращаются], руки мыюць, ўсе прыязжаюць, хто го покойника на том свете. И через год благочинный дает добро и батюшка отпевает. Если умерло некрещеное дитя, это очень плохо, для этого ребенка плохо. Я знаю, когда рождались слабенькие дети, то их старались как можно скорее окрестить, чтоб не умер. Если ребенок умер, уже ничего не сделаешь, это уже замаливали, ходили в церковь и молились за него. Таких детей хоронили на общем кладбище, а не отдельно. И говорили, что дитя там плачет, его не пускают к другим покойникам [ПТФ, БВВ] (Оранчицы).

1. Последний покойник сторожит кладбище, а следующий его сменяет [СЛЯ] (Клетное).

2. Говорят раньше и теперь, что новый покойник сменил предыдущего на дежурстве на воротах. Тот стоял на воротах до сих пор. Мне приснилась умершая мама, когда в селе был покойник и говорит: «Пойдемте все встречать Колю, будем встречать Колю» [РЕИ] (Ровбицк).

3. Если в селе кто-то умер, а после долго нет другого покойника, то мы говорим, что долго он на посту стоит, пока нет другого покойника. А следующий покойник сменяет предыдущего. Некоторые быстро, а некоторые долго стоят [ПЕА] (Клепачи).

1. Когда с кладбища возвращаются на поминки, моют руки. Когда-то мама мне 
да стала [поминального]. [Прикладывали ли руки к печи?] Некали маци мая мне гаварыла, есьли ты зимою идзешь ат пакойнаго, прыложы руки да пе́чы, не [будут] руки холаду баяцца. Вот правяли пакойника, прышла и прылажы руки да печы. Или прышла атведаць, хто там памьёр, [вернулась] да хаты и прылажы руки да печы [CEВ, ПЕА] (Клепачи).

2. [Что делали дома после похорон?] Астаюцца ж людзи, моюць пол, ўсё памыли и ужэ ставяць сталы, накрываюць, прыходзюць сразу после кладбишча и трэба ўсем мыци руки мылом, и ручник специяльно чыстый даецца; помылиса и сели за стол [поминать покойника] [ПЛВ] (Хорева). говорила, что если ты зимою идешь от покойника, приложи руки к печи и они не будут мерзнуть. Вот проводили поконика на кладбище, пришла и приложи руки к печи. Или если ты пришла в дом покойника навестить его до похорон, вернулась домой и приложи руки к печи [CЕВ, ПЕА] (Клепачи).

2. Когда покойника увезли хоронить, в доме остаются люди, они моют пол, ставят и накрывают поминальные столы. Когда люди возвращаются с кладбища, всем следует вымыть руки с мылом и специально дается чистое полотенце, помыли руки и садятся за стол поминать [ПЛВ] (Хорева).

\section{Поминальная обрядность}

\section{Поминки личные}

1. [Какие бывают поминки?] [В день похорон], тры дня и дзевяць дней, и сорак дней, и поўгода. Прыменна, сваих дзяцей далёких [на эти поминки] не звали, в цэрковь завшэ паминали. Панихиду дзелали. И год, там настаяшчэе - ўсех кличеш. [Все поминки справляются одинаково или есть разница?] Дзевяць дней абычна, хто абмывал пакойника, хто магилу капал и хто самые близкия. Сорак дней масаво прыглашаецца и хто сможэт прыехаць. < ..> [Расскажите про поминки]. Запаливаецца сьвечка и бацюшка сьпявае. Купляеш такие сьвечки новыя, ў руках ўсе дзержат и ужэ гэци сьвечки запаливаеш. Встаюць, памоляцца, хто якие малитвы знае, хто большэ, хто меньшэ, и тады жэ даюць той кашы [кутьи], сразу каждаму па ложце. У нас варыли кашу рыс, ужэ бацюшка яго асвециць, атпявае пакойника, и в первую очэрадзь кашу йетаю [освятит], патом ужэ [можно] пици и есьци. [Звали ли душу покойника на по-
1. Поминки отмечают в день похорон, три дня, девять дней и сорок дней, и полгода. На эти поминки не приглашали детей, если они далеко живут, всегда ходили и поминали в церкви, заказывали панихиду. А на год устраивали настоящие поминки, приглашали всех. На девять дней приглашали тех, кто обмывал покойника, кто копал могилу и присутствуют близкие родственники. На сорок дней приглашали всех, кто сможет приехать. На поминках зажигали свечу и батюшка пел молитву. Покупаешь новые свечки, их зажигают и держат в руках все присутствующие. Встают, молятся, кто какие знает молитвы, кто больше, кто меньше, и каждаму дают по ложке каши (кутьи). У нас варили рис, его освящал батюшка, когда отпевал покойника - в первую очередь освящал эту кашу - а потом уже можно есть и пить (на поминках). На поминки приглашали душу умершего, помолились и говори- 
минки?] Ну а як жэ, памолишся и: «Прыходзь на вячеру». [Ставили ли ему еду?] Яду́ ставили, а на другой дзень нясли [её] на кладбишчэ. Тарэлочка пасрэди стала стаяла и сьвечка горыць, людзи ўсе дзержаць маленькие сьвечки; гэта сьвечка ўсю вячеру гариць, а ужэ геци маленькие сьвечки [которые держат в руках], тушат и ядзяць, а в канцэ зноў гэтая малитва гаварыцца [ПЛВ] (Хорева).

2. Йесьли и памрэ челавек, сягодня канфетами крэсцик [на каше выкладывают]. Як бацюшка атпявая, тада этая каша далжна стаяць на гэтой, с крэсцикам, ён пасвянцае, а [когда] пахаранили, тую кашу на вячэре разабрали, чуць паели и ўсё. Ў дзень пахарон. <..> [Ставили ли еду для покойника?] Свянцону воду ставяць и хлеб ложаць, и ставяць яму гэту чарку, водку наливаюць, яшчэ што паложуць [на поминках] [CEВ, ПЕА] (Клепачи).

3. Трэба, як пахаваюць, трэба, каб сорак дней ляжала булка хлеба и вада, [надо] меняци кажный ранак воду. [Куда это потом девали?] Ну, куды, ў плиту, ў печчу. Курам размочыш, скацине аддаш. [Вешали ли полотенце на окно?] Ну, у нас вешаюць, вешали [КОИ] (Клетное).

4. [Куда девали остатки еды с поминок?] Ну, кажуць, што трэба птушкам аддаваць, хлеб выносили. Ну, гэто раньшэ аставалась мало, а цяпер многа астаецца и сами используют [РЕИ] (Ровбицк).

\section{Второй день}

1. [Поминали ли покойника наутро на могиле?] Абычна [на поминках в день похорон] наливали чарку, ставили тарэлочку, на тарэлочку клали хлеба и закуски немножко. И ужэ утрэчком прачынаюцца, родственники самые близкие ужэ, и шли «будзици» на кладбишшэ. Шли ли: «Приходи на ужин». Ему ставили специальную еду, а на следующий день ее относили на кладбище. Эта тарелка стояла посреди поминального стола и рядом горела свечка, и все люди держат маленькие свечки; свечка возле тарелки горела на протяжении всех поминок, а маленькие свечки, что люди держали в руках, тушили и садились есть, а в конце поминок снова читалась эта молитва [ПЛВ] (Хорева).

2. Когда умирал человек, варили кашу, теперь на ней конфетами выкладывают крестик. Когда батюшка отпевает покойника, эта каша стоит и он ее освящает, а после похорон на поминках всем раздавали немного этой каши. Для покойника ставили освященную воду и клали хлеб, и ставили чарку с водкой, клали и еще что-нибудь ему на поминках [CEВ, ПЕА] (Клепачи).

3. Когда покойника похоронят, нужно, чтобы в его доме сорок дней лежала булка хлеба и стояла вода, которую меняли каждое утро. Это потом бросали в плиту, в печь, хлеб размачивали курам, отдавали скотине. На окно вешали полотенце [КОИ] (Клетное).

4. Говорили, что остатки еды с поминок нужно отдать птицам, им выносили хлеб. Раньше оставалось мало еды, а теперь ее остается много и ее едят сами [РЕИ] (Ровбицк).

1. На поминках после похорон обычно наливали чарку для покойника, ставили ему тарелочку, на нее клали хлеб и немного закуски. А уже утром на другой день просыпались самые близкие родственники и шли покойника «будить» на кладбище. Шли с бутылкой и несли 
будзици и шли с бутылкаю, и занесли тую чарку, там паставили на кладбишчэ, и все, хто зашоў, там с им паздаровались: «Як ты праспаў ноч?». И гэтые да хаты ўжэ идуць, и тую яду́ на магиле астаўляли. И дома [снова] паминали [ПЛВ] (Хорева).

2. [Ходили ли на второй день на кладбище?] Хадзили, казали: «Пашли, будзиць будзем, будзиць» [CВМ] (Староволя). ту чарку (что стояла на поминках), ставили на могиле и все с умершим здоровались: «Как ты проспал ночь?» И снова шли домой, а ту еду (с поминок) оставляли на могиле, и дома снова поминали [ПЛВ] (Хорева).

2. На второй день ходили на кладбище, говорили: «Пошли, будить будем» [СВМ] (Староволя).

\section{Календарная поминальная обрядность}

\section{Деды ${ }^{1}$}

1. [Когда бывают деды?] Перад кажным сьвятом. Гэта осенью, и тады перад Калядами и перад Вяликаднем радзительская субота, пост перад Пасхай. Тры суботи. И зарэ перад Троицэй, зарэ буде дзедова субота, паминальная. Дзяды и радзицельская атдзельна. А дзяды эта осенью. У наябрэ, Дмитриевские, то тые все кались, казали, Дмитровские польския, а зарэ кажуць, Дмитриевские правильно, а чэраз тыждзень были наши православные, на другу суботу наши православныя. Так мы и справляем. <.. > Ну да, як тая дзядовая нядзеля, ужэ кались вячэру гатовили, сьвячкы запаливали и куццю варыли и паминали. Памоляца, памянуць. Ну, казали, трэба, коб на стале аставалося. А зарэ так не испалняюць [КОИ] (Клетное).

2. Е дзяды втарога акцября, навернае, ци наября. Тожэ на кладбишчэ йдуць, ў церкву йдуць $<\ldots>$. [Делали ли дома вячэру?] Дзелаюць. Напрымер, як йесьць сямья, дастанем пару тых мисак и астаўляем на стале на ноч, не ўбираем; дзелаюць. [Приглашали ли души?] Га-

${ }^{1}$ Домашняя поминальная обрядность, посвященная всем умершим предкам рода и состоящая обычно из ужина в кругу семьи, куда приглашаются души умерших.
1. Деды бывают перед каждым праздником. Это осенью и перед Рождеством, и перед Пасхой родительская суббота, в пост перед Пасхой. Три субботы. И сейчас перед Троицей, будет дедовская суббота, поминальная. Деды и родительские дни это разное. Деды - это осенние поминки. В ноябре дмитровские деды, но они, говорили, польские, а сейчас говорят, что дмитровские - это правильно, а через неделю от них были наши православные, на следующую от них субботу. Так мы и справляем. <...> Ну да, в дедовскую неделю ${ }^{2}$ готовили ужин, зажигали свечки, варили кутью и поминали мертвых. Помолятся, помянут. Ну, говорили, что нужно оставлять остатки еды после ужина на ночь на столе. А сейчас так не делают [КОИ] (Клетное).

2. Есть деды второго октября, наверное, или ноября. Идут в этот день на кладбище, в церковь. Дома устраивают поминальный ужин; когда семья ест, на

\footnotetext{
2 Скорее всего, любая неделя, на которую попадает какой-либо поминальный день. Помимо этого, в Полесье этим термином обозначается также неделя Великого поста, предшествующая Масленой неделе; последняя неделя рождественского поста (Толстая 2005: 74).
} 
вораць, гэта гаворяць. [Ставили ли им отдельную еду?] Ну, ставили, чарку ставим, водки налиць, што-нибуць яшчэ. $<\ldots>$ [Сколько дедов в году?] Адные. Восеньню. Няма вясною ничаго» [CEB, ПЕА] (Клепачи).

3. «У нас дзядоў перад Раждзеством, перад началом Раждзественскаго по́ста, [в] воскрасенье были дзяды, у нас называли Михайлаўские дзяды, Дмитраўских дзядоў у нас да паследняго врэмени не было, не шчытаецца, гэта можэ большэ каталичэские, якая памяць пра тых, хто пагибшие, ваенаабязанные. < ..> А следуюшчыя дзяды - гэто перад началом Вяликаго паста, ужэ не так, Прашчоная васкрэсенье, ужэ вспаминаюць, но гэта не так [обязательно]. Радзицельская субота перад Троицай, гэто да. [Что делали в эти дни?] Проста в цэрковь [ходили]. Других няма. На вечар кликали [приглашали родных], наябрь, дзень кароткий» [РЕИ] (Ровбицк).

\section{Пасхальный цикл}

1. Як Паска, идуць ў срэду, шчтаецца у нас Градавая серэда ${ }^{1}$, вяками становицца, што идуць на кладбишчэ. [Что там делают?] Бацюшка атпевае, магилки сьвенцаюць, цьвяты несуць, перэд гэтым стараюцца все магилки ачысциць, штоб было красиво, прыбираюцца и красюць, и мятуць, и цвяты ставяць. Бацюшка атпеваець там на дароге малитву гэтым пакойным. [Есть ли Про-

\footnotetext{
${ }^{1}$ Среда на пасхальной неделе, перед или после Троицы; праздник, в основном известный в Полесье запретом на разные виды работ, в первую очередь сельскохозяйственных, в целях защиты от града.
}

стол ставили пару мисок (для душ) и их вместе с остатками ужина оставляли на столе на ночь. К поминальному столу приглашали души умерших, им ставили чарку водки и чего-нибудь еще. Деды бывают один раз в год, осенью [CЕВ, ПЕА] (Клепачи).

3. У нас деды справляют перед Рождеством, перед началом рождественского поста в воскресенье, у нас их называли Михайловские деды, Дмитровских дедов у нас не было вплоть до последнего времени, их не отмечали, это, может, больше католический праздник, поминки по погибшим на войне, военнообязанным. А следующие деды - это перед началом Великого поста, они не такие обязательные, Прощеное воскресенье, поминают, но это не обязательно. Родительская суббота бывает перед Троицей. В поминальные дни просто ходили в церковь. Другого ничего. (На осенние деды) на ужин приглашали родных, ноябрь, день короткий [РЕИ] (Ровбицк).

1. Испокон веков на кладбище ходили в Градовую среду на пасхальной неделе. Батюшка служит панихиды, освящает могилки, на них приносят цветы, а перед этим стараются все могилы почистить, чтобы было красиво; убираются и красят, и метут, и ставят цветы. Батюшка на дороге поет заупокойную молитву. Проводной среды у нас нет. А в некоторых местах это делают на Проводную среду, а у нас в Градовую. Радуницу не отмечают [CЕВ] (Клепачи). 
воды ${ }^{1}$ ?] А Правадная середа у нас нет. А в некоторых местах на Правадную робяць, а у нас ў Градавую сераду робяць. [Есть ли Радуница?] У нас не было гэтаго [СЕВ] (Клепачи).

2. На кладбишча раньше хадзили ў восянь, ета такие дзяды, забыла якого числа, хадзили, паднавляли магилки и усё, на Радуницу хадзили вясной, <..> в воскрасенье [следующее после Пасхи] и зараз бацюшко освяшчает магилки и атправляе как паложено. <..> И яйца уссё насили, на Пасху. [Как говорили у вас: Радуница или Проводы?] Правадная нядзелька. Нихто не знаў, што Радуница, это уже зараз так. У нас Правадная нядзелька. Ну и гаварыли, хто умрэ на Пасху, гэта шчастливый чалавек, и на Раждяство, и Гасподь ўсем ўсё прашчае и бярэ в царство нябеснае [РНП] (Юндилы).

3. Ёсь Радуница, но у нас не на Радуницу, а на Провады [ходят на кладбище], кали Паски Правадная [неделя], это тут [в Оранчицих]; а у нас - Навский вяликдзень ў чатьверг [в Жогалах]. В васкрэсенье Правадная. Ну, па правдзе такого праздника Радуница раньше не слышали, и да сих пор не вспаминаюць, и не ходзяць [на кладбище], хадзили в Правадную и в Навский вяликдзень и так и ходзяць. [Что в этот день делали на кладбище?] Там бацюшка абычна идзет в тот дзень, высвечивае магилки, все родственники прыезжаюць, стаяць, раньше, я помню, выпивали и закусывали, щас уже этаго нет, а раньше и там сидзяць [на могилах с едой], и там... А щас пастаяць, цветы паставили и дамой.

\footnotetext{
${ }^{1}$ Проводная неделя - неделя после Пасхи, Проводы — воскресенье на этой неделе. Имеет в Полесье преимуществено поминальную семантику (проводы на кладбище душ умерших, которые на Пасху были в домах своих родных, поминки на могилах), а в Брестско-Пинском Полесье представлен еще мотив проводов зимы (Толстая 2005: 197).
}

2. На кладбище раньше ходили осенью на деды, забыла какого числа, ходили, убирали могилки и все; на Радуницу ходили весной, в следующее воскресенье после Пасхи и теперь батюшка освящает могилки и служит, как положено. И на Пасху все носили на могилы яйца. У нас было Проводное воскресенье. Никто не знал, что такое Радуница, это теперь стало так. У нас было Проводное воскресенье. Ну и говорили, что тот, кто умер на Пасху, счастливый человек, то же самое на Рождество, Господь им прощает все грехи и берет в царство небесное [РНП] (Юндилы).

3. Есть Радуница, но у нас ходят на кладбище не на Радуницу, а на Проводы после Пасхи, так делают в Оранчицах. А у нас в Жогалах - в Навский великдень в четверг (на пасхальной неделе). В воскресенье - Проводы. По правде, такого праздника, Радуница, раньше не было и сейчас его не отмечают, на кладбище не ходят; на кладбище ходят и ходили в Проводы и в Навский великдень. В этот день батюшка обычно идет на кладбище, освящает могилки, приезжают все родственники, раньше, я помню, там выпивали и закусывали, сидели на могилах с едой, а сейчас этого нет. Сейчас постоят, цветы поставят и идут домой. Кто хочет, поминает дома, а рань- 
Хто хочет, дома паминаець, а раньше сидзели там, на кладбишчах. Помню, там сидзяць, там сидзяць, там... все на кладбишчах сидзяць, аставляли там и яйца, и всякие [угощения]; ну а щас бацюшка сказаў: «Не аставляць, а то и петухи, и сабаки ходзяць». А ешче помню, водку наливали [оставляли на могиле], абязацельно, алкашы ешче хадзили и патом выпивали, зараз бацюшка наказаў строга: «Кроме цветов ничего» [БВВ, ПТФ] (Оранчицы).

4. [Когда ходили на кладбище?] У нас ходюць после Великадьня. Провады ужэ бываюць, Правадная нядзеля, хадили ужэ на магилки. Тыздзень посля Вяликодня и ў нядзелю. [Была ли Радуница?] Радуницы у нас не было, эта ужэ зарэ прыдумали. Казали, Чушкевич [Шушкевич] яе выдумаў. Начаўник быў [СЛЯ] (Клетное).

\section{Cпrac}

1. [Носили ли яблоки на Спаса ${ }^{6}$ на кладбище?] Ягоды не знаю, а яблоки у нас носяць. Ну, ўроде бы угашчали умершых. Мама мая казала: «Мы едзим и им трэба». И яблаки, и грушы и зараз лежаць [РЕИ] (Ровбицк).

2. Кагда мы идзем ў церковь яблаки сьвенцаць, тады мы на кладбишчэ каждый раз идзем, сьвенцаем яблаки и идзем на кладбишчэ ў гэтый Спас ${ }^{1}$. [Клали ли яблоки на могилы?] Раньше клали некаторые, а теперь не ложым. [Можно ли есть яблоки до Спаса?] У каго маленькие дзеци умирали, нихто не есьць. У каго дзеци взрослые - можно есьци. У каго маленькие не ядуць, напрымер, маци мая не ела яблока да Спаса, у нее умирали [дети]. [Говорили ли, что ребенку тогда на том свете не дадут яблока?] Гаварыли, гаворюць [CЕВ] (Клепачи). ше это делали на кладбище. Помню, и там сидят (на могиле), и там... все на кладбище сидят, оставляли потом там яйца и всякие угощения, а сейчас батюшка сказал: «Не оставлять, а то петухи, собаки ходят». А еще помню, водку обязательно наливали и оставляли на могиле, алкоголики ходили потом и выпивали, а теперь батюшка строго запретил: «Кроме цветов ничего» [БВВ, ПТФ] (Оранчицы).

4. На кладбище у нас ходят после Пасхи. Бывают Проводы, Проводная неделя, ходили на могилки. Неделя после Паски и воскресенье на этой неделе. Радуницы не было, это уже сейчас придумали. Говорили, что Шушкевич ее выдумал, это начальник был [СЛЯ] (Клетное).

1. Про ягоды я не знаю, а яблоки на кладбище на Спаса у нас носят. Вроде бы, угощали умерших. Моя мама говорила: «Мы едим и им нужно». И яблоки, и груши и теперь лежат на могилах [РЕИ] (Ровбицк).

2. Когда мы идем в церковь святить яблоки, тогда каждый раз заходим на кладбище, освящаем яблоки и идем на кладбище в этот Спас. Раньше на могилы клали яблоки, а теперь нет. У кого умирали маленькие дети, тому запрещено до Спаса есть яблоки, а у кого взрослые - можно. Не едят те, у кого умирали маленькие, моя мама не ела яблок до Спаса, у нее умирали дети. Говорили и говорят, что тогда этому ребенку на том свете не дадут яблока [CEВ] (Клепачи).

\footnotetext{
${ }^{1}$ Праздник Преображения, 6/19 августа.
} 


\section{Ходячий покойник}

[А мог покойник приходить?] Казали, што кались, бабуля тожэ рассказывала, што прыходзиў, и юн скажэ, што рабиць и все знаў и падсказываў, спрыяў, хадзиў. [А умершая мать не приходила к ребенку?] Ну, тожэ казали, што прыходзиць, казали, к маленькому прыходзила, цыцки давала, чули, диця ссёт. [Что с этим ребенком стало?] Вырасло, пажанилося, ничого дрэннаго не было [КОИ] (Клетное).
Говорили и бабуля тоже рассказывала, что покойник мог приходить, и что он посоветует, что делать, все знал и подсказывал, помогал, ходил. Умершая мать, говорили, тоже может приходить к ребенку, кормила его грудью, (остальные) слышали, как ребенок сосет. С эти ребенком ничего плохого не случилась, он вырос, женился [КОИ] (Клетное).

Как хорошо видно из представленного в статье материала, комплекс погребальной и поминальной обрядности Пружанского района до сегодняшнего дня остается богатым, хорошо разработанным и сохраняющим множество архаических черт. Однако, на вопросы о нем информанты, как правило, отвечают менее охотно, чем рассказывают о свадьбе и родинах. Чтобы восстановить последовательность ритуальных действий и связанных с ними мифологических представлений, почти всегда требовались дополнительные вопросы собирателя. Причем эта тенденция касалась не только обычных людей, но и тех респондентов, которые обычно помогали односельчанам в погребении, навещали покойников, ходили их обмывать, читать по ним и устраивать поминки.

Нельзя не сказать несколько слов о трансформациях традиционной культуры, фиксирующихся в Пружанском районе, которые прекрасно заметны на материале похоронно-поминальной обрядности. Наряду с сохранностью практически полной номенклатуры сюжетов и ритуальных действий в данном ритуальном цикле, таких как приметы, поверья, запреты, обрядность похорон, снаряжение покойного, действия при выносе и движении погребальной процессии, бужение покойного на могиле на второй день; поминки, домашняя обрядность на дедbl, весенне-летний цикл, эортологическая терминология (Навский великдень, Проводы, Проводная неделя и пр.), специфические поминальные обычаи, приуроченные к празднику Спаса и церковному освящению плодов, поверья о ходячих покойниках, помощи мертвых живым; представления о последнем умершем, охраняющем кладбище, воспоминания о запрете хоронить на погосте «нечистых» покойников, их связь с метеорологическими явлениями (ветер, буря, засуха, дождь) и пр., заметно значительное размывание большой части поминальной обрядности и в первую очередь, обычаев календарного цикла поминок.

Весьма ощущается редукция дедовского поминального обряда. Многие респонденты отвечали, что вечерю не делали, души умерших на ужин не звали, ходили вместо этого с ближайшими родственниками в церковь и на кладбище. О количестве дедов в году они отвечали по-разному, но в некоторых случаях их количество ограничивалось одним-двумя днями в год, часто не отмеченными специфической обрядностью - в отличие от пяти-шести поминальных дат в течение года в других районах Полесья и соседних регионах (Полесский архив, Виноградова, Толстая 1999, ПМА). Помимо этого можно выделить характерное для народной культуры вообще и уже 
не раз отмеченное исследователями исчезновение погребальных норм, касающихся «нечистых покойников», в первую очередь, запрета хоронить их на общем кладбище. Вместе с тем интересна сохранность связанной с этой группой умерших окказиональной обрядности - вызывание дождя на могиле висельника и обычай для предотвращения засухи кидать на похоронах в его могилу бутылку с водой (Юндилы).

Также можно говорить об исчезновении в данном районе традиции совершать поминки на кладбище в весенне-летние поминальные дни, включавшие в себя ранее, помимо уборки и обновления захоронений, массовый выход населения на кладбища, накрывание «стола» на могилах, приглашения к нему душ, обеда, оставления после него еды и других подарков покойным. Ныне эти обычаи практически полностью заменены церковными формами почитания мертвых (посещением могил, церквей и заказыванием заупокойных служб, церковными панихидами на кладбище). Постепенно отмирают и другие формы традиционной обрядности: исчезают обычаи застилать гроб скатертью на похоронах, бросать деньги в могилу, навещать умерших родственников на Спаса, оставлять на могилах яблоки и пр., что часто происходит из-за осуждения архаических ритуальных приемов священиками. Наряду с этим отмечается и появление новых на этой территории обрядов: включение в весенний поминальный цикл празднования Радунищь (в отличие от исконных Навских проводов на пасхальной неделе). Среди маргинальных мотивов можно отметить упоминание Градовой среды в числе поминальных дней (Клепачи). Любопытен и запрет заготавливать заранее смертную одежду (Хорева).

Интересной особенностью семейной обрядности Пружанщины является отмеченная экспедицией связь между комплексом похоронно-поминальной обрядности и свадьбой. Так, в Ровбицке удалось зафиксировать, что особым образом маркированы первые деды после свадьбы: «Были дзяды, цёшчя зяця кликала, як первыя дзяды были после свадзьбы, ужэ абязацэльно прыглашали ўсю радню. Была такая гулянка» [Были дедbl, тещя зятя приглашала на первые деды после свадьбы, уже обязательно приглашали всю родню. Была такая гулянка.] [РЕИ]. Можно предположить, что посредством совершения совместного поминального обряда, куда приглашались души предков обоих родов, окончательно закреплялось слияние двух семейств, и ритуально подкреплялся статус новообразованной семьи.

В Пружанском районе записаны несколько редких для традиции мотивов, например, возможность отмолить самоубийцу с помощью раздачи конфет людям и кормления птиц, а также представления о существовании душ умерших животных, которые в некоторых случаях встречают умершего человека вместе с другими душами на «том свете». Например, в тексте из Клепачей (см. выше: Процессия, №6) рассказывается, как умершую женщину в потустороннем мире встречала душа собаки со свечой. В исследованном регионе удалось записать аналогичную быличку с тем же сюжетом, но вместо собаки в ней упоминалась душа умершей лошади [CВМ] (Староволя). Это позволяет говорить о неслучайности такого мотива в традиционной духовной культуре. Также зафиксирована сохранность специфической терминологии, касающейся смерти животных, а именно противопоставление на уровне лексики смерти пчел и гибели всего остального домашнего скота и птиц. Только о пчелах, имеющих в народном сознании особый статус, говорили, что они умерли: «Карова здохла, кот здох и свиння здохла и ўсе так гаварыли; кажуць, што пчолка умерла працавитая пчолка» [Корова сдохла, кот сдох и свинья сдохла и все так говорили, говорят, что трудолюбивая пчел- 
ка умерла] [CEВ, ПЕА] (Клепачи); «Карова здохла и конь здох, пчолы - памор напаў» [Корова сдохла и конь сдох, пчелы - мор напал] [РЕИ] (Ровбицк).

Заметны также диалектные различия в терминологии, имеющей отношение к погребальному обряду. Например, в Оранчицах глагол кана́ц̧ь 'агонизировать; умирать’ имеет отрицательное, пренебрежительное значение, а в Юндилах, как и в других областях Полесья, этот термин нейтрален.

Другие отмеченные примеры терминологии из обследованного региона: cmapbк, сход 'убывающий месяц', маладзик 'растущая луна', поўня 'полнолуние'; свеце́u ‘фаза три четверти' (Ровбицк); брат брата на вилах дзержыт (Клепачи), дзевушка с карамыслом (Смоляницы) 'лунные пятна'; карамысло 'радуга', барада, каза ‘последний сноп', палиць ведзьму 'Купала' [ПТФ] (Жогалы) и пр.. В Ровбицке еще записан любопытный факт, связанный с демонологическими представлениями: «Як начыналось спець жыто, казали «расило жито», «расило жыто на поле», тады ўжэ казали, што па полю ходзюць русаўки. Знаеце, калосья, висяць якие бы капельки расы, цвеце ано. И пагэтаму русаўки хадзили па яму» [Когда начинало спеть жито, говорили «росило жито», «росило жито на поле», тогда говорили, что по полю ходят русалки. Знаете, на цветущих колосьях словно бы капельки росы висят. И поэтому русалки ходили по нему (полю)] [РЕИ]. Приведенный пример дает интересную параллель к болгарскому поверью о том, что русалийки окропляют всходы жита живительной влагой, чтобы усилить их рост [Етнографски проблеми: 63]. Ср. также: «русалки седзяць ў жыци, як ено расуе. Ета Бог их посылае пильнаваць, штоб нихто не тоўкса да не трусиў каласкоў, бо не наллюцца» [Русалки сидят в житном поле, когда оно цветет. Это Бог их посылает стеречь, чтобы никто не толкся и не тряс колосья, иначе они не вызреют] (полес.) [Pietkiewicz 1938: 186].

\section{Список населенных пунктов и информантов}

\section{Клепачи}

СЕВ - Семко Евгения Васильевна 1939 г.р., местная, православная.

ПЕА - Петроневич Евгения Антоновна 1939 г., р., местная, православная.

\section{Клетное}

КОИ - Козловская Ольа Иосифовна, 1937 г.р., местная, православная, 5 классов образования. СЛЯ - Сушко Лидия Яковлевна, 1933 г.р., местная, православная.

\section{Оранчицы}

БВВ - Бартынева Валентина Владимировна, 1955 г.р., местная, православная.

ПТФ - Пушко Татьяна Филлиповна, 1935 г.р., род. д. Жогалы Пружанского р-на, окончила педучилище.

\section{Ровбицк}

РЕИ - Романовская Елена Ивановна, 1950 г.р., местная, православная.

\section{Смоляницы}

ЯЛМ - Яроцкая Людмила Михайловна, 1961 г.р., местная, работник дома культуры. 


\section{Староволя}

СВМ - Слобода Валентина Матвеевна, 1945 г.р., родилась в д. Мелихови́чи, раньше был Ружанский район (60 км. от Староволи).

\section{Хорева}

ПЛВ - Панасевич Лидия Васильевна, 1932 г.р., местная, православная.

\section{Юндилы}

РНП - Ракуть Нина Петровна, 1940 г.р., местная, православная.

Собиратели: Андрюнина М.А., Антропов Н.П., Боганева Е.М., Володина Т.В.

\section{Источники и материалы}

Винорадова, Левкиевская 2010 - Винорадова Л.Н., Левкиевская Е.Е. (сост.) Народная демонология Полесья. Т. 1. М.: Языки славянских культур, 2010.

Полесский архив - Полесский архив сектора этнолингвистики и фольклора Института славяноведения РАН, рукопись, Москва.

ПМА - Полевые материалы Андрюниной М.А., рукопись, Москва.

\section{Научная литература}

Виноградова Л.Н., Толстая С.М. Деды / Славянские древности. Этнолингвистический словарь / под общей ред. Н.И. Толстого. Т. 2, М., Международные отношения, 1999. С. 43-45.

Генчев С. (съст.) Етнографски проблеми на народната духовна култура. Т. 1. София, 1989.

Кухаренко Ю.В. Памятники железного века на территории Полесья. М., 1965.

Кухаренко Ю.В. Полесье и его место в процессе этногенеза славян (по материалам археологических исследований) // Полесье. Лингвистика. Археология. Топонимика / отв. ред. В.В. Мартынов, Н.И. Толстой. М.: «Наука», 1968. С. 18-46.

Мартынаў В.У. Уводзіны // Лексіка Палесся ў прасторы і часе / рэд. В.У. Мартынаў. Мінск, 1971. C. 3-35.

Толстая С.М. Полесский народный календарь. М.: Индрик, 2005.

Толстой Н.И. О лингвистическом изучении Полесья (предисловие редактора) // Полесье. Лингвистика. Археология. Топонимика / отв. ред. В.В. Мартынов, Н.И. Толстой. М.: «Наука», 1968. С. 5-17.

Pietkiewicz Cz. Kultura duchowa Polesia Rzeczyckiego. Materiały etnograficzne. Warszawa, 1938.

\section{References}

Genchev, S. (ed.) 1989. Etnografski problemi na narodnata duhovna kultura. Sofiya [Ethnografical Problems of Spiritual Folk Culture]. Vol. 1. Sofia.

Kuharenko, Yu.V. 1965. Pamyatniki zheleznogo veka na territorii Poles'ya [Iron Age Artefacts from Polesye Territory]. Moscow.

Kuharenko, Yu.V. 1968. Poles'e i ego mesto v processe etnogeneza slavyan (po materialam arheologicheskih issledovanij) [Polesie and its place in the process of ethnogenesis of the Slavs (based on archaeological research)]. In Poles'e. Lingvistika. Arheologiya. Toponimika [Polesie. Linguistics. Archeology. Toponymy], edited by V.V. Martynov, N.I. Tolstoj, 18-46. Moscow: «Nauka».

Martynov, V.U. 1971. Uvodziny [Foreword]. In Leksika Palessya y̆ prastory i chase [Polesye Lexics in Space and Time], edited by V.U. Martynay̆ , 3-35. Minsk. 
Pietkiewicz, Cz. 1938.Kultura duchowa Polesia Rzeczyckiego. Materiały etnograficzne. [Pietkiewicz Cz. Spiritual Culture of Rechitsa Polesye Region. Ethnografical Data]. Warszawa

Tolstoj, N.I. 1968. O lingvisticheskom izuchenii Poles'ya (predislovie redaktora) [On Linguistic Studies of Polesye (Foreword of Editor)]. In Poles'e. Lingvistika. Arheologiya. Toponimika [Polesye. Linguistics. Archeology. Toponymy], edited by V.V. Martynov, N.I. Tolstoj, 5-17. Moscow: «Nauka».

Tolstaya, S.M. 2005. Polesskij narodnyj kalendar' [Polesye Folk Calendar]. Moscow: Indrik.

Vinogradova, L.N., and S.M. Tolstaya. 1999. Dedy [Forefathers]. In Slavyanskie drevnosti. Etnolingvisticheskij slovar' [The Slavic Antiquites. Ethnolinguistic Dictionary], edited by N.I. Tolstoj, Vol. 2, 43-45. Moscow: Mezhdunarodnye otnosheniya.

Andrunina, Maria A.

\section{Funeral and Remembrance Folk Customs of Pruziany Region Based on 2019 year's Field Data from Pruzhiany Region of Brest Province of Belorussia}

The article presents the collection of folk narratives conscierning grave customs gathered during recent field research in western Polesye (Brest province). Along with the remarkable preservation of the ancient lore in the said region innovations were founded (for exp. new for this part spring remembrance date - "Radounitsa"), mechanisms of disintegration of tradition are highlighted, which are often due to extinction of subjects and practices (exp. craft of weaving, birth at home) or interference from the Church prohibiting a lot from the pagan remembrance and funeral practices, semantic parallels with another Slavic areas are outlined (exp. the connection between "rusalka" (female mythological creature), dew and fertility in Polesye and Bulgaria). Also the paper includes some motives from the other parts of tradition, for example, demonology, lunar time measure, occasional rites (rain invocation), festivals etc.

Key words: Polesye, field data, funeral, remembrance, traditional culture 